\title{
The Use of Authentic Materials in "Cambridge Primary English Stage 4 Learner's Book" to Teach Reading (A Case Study)
}

\author{
Endah Aprilia Purwaningrum, Dewi Rochsantiningsih, Ngadiso \\ Sebelas Maret University, Surakarta, Indonesia \\ endah.aprilia.p@gmail.com
}

\begin{abstract}
Abstrak
Penelitian ini bertujuan untuk: (1) mengidentifikasi materi otentik yang ada pada buku "Cambridge Primary English Stage 4 Learner's Book" yang telah diimplementasikan untuk mengajar membaca; (2) mendeskripsikan bagaimana materi otentikyang telah diimplementasikan untuk mengajar membaca; (3) mendeskripsikan permasalahan yang dihadapi guru dalam mengimplementasikan materi otentik untuk mengajar membaca dan solusi yang dipaparkan. Penelitian ini merupakan penelitian kualitatif studi kasus yang dilaksanakan di Sekolah Dasar di kota Surakarta. Subjek yang dipilih adalah guru bahasa Inggris yang mengajar di level 4 program kelas internasional. Data dari penelitian ini diperoleh dari observasi, wawancara, dan analisis dokumen. Seluruh data dianalisis dengan menggunakan model interaktif yang dipaparkan oleh Miles, Huberman, dan Saldana (2014). Hasil dari penelitian ini adalah: (1) Materi-materi otentik yang digunakan dari buku Cambridge Primary English Stage 4 Learner's Book pada semester 1 untuk mengajar membaca adalah a) Poster, b) Sampul Buku, c) Kartu, d) Indeks Buku, e) Blurb. (2) Implementasi dari penggunaan materi-materi otentik dari Cambridge Primary English Stage 4 Learner's Book adalah: a) Poster digunakan untuk mengajarkan unsur-unsur cerita narasi, b) Sampul buku digunakan untuk mengajar isi cerita yang terdiri dari judul, tokoh, setting, alur dan suasana cerita, c) Kartu digunakan untuk mengajar teks deskripsi, d) Indeks buku digunakan untuk mengajar informasi beruntun, e) Blurb digunakan untuk mengajar cara mengidentifikasi isi buku cerita, hampir seluruh materi-materi otentik digunakan pada awal pengajaran. (3) kesulitan utama yang dihadapi siswa adalah: a) rendahnya pemahaman tata bahasa Inggris siswa, b) kesulitan dalam memahami isi materi otentik, c) kemampuan berbahasa Inggris siswa rendah berkenaan dengan fungsi tata bahasa, d) kemampuan fokus bahasa siswa berkaitan dengan kalimat-kalimat yang digunakan pada materi otentik rendah, e) perbendaharaan kosa kata siswa lemah. Empat solusi yang telah dipaparkan oleh guru adalah (a) memberikan kosa kata baru dan stimulasi kata kepada siswa, (b) mempelajari contoh materi otentik lain yang berhubungan dengan materi yang sedang dibahas di kelas, (c) melakukan diskusi dengan siswa dan (d) meningkatkan pemahaman siswa tentang materi yang sedang dibahas.
\end{abstract}

Kata Kunci: Materi Otentik, Cambridge English Textbook, Membaca.

\section{Abstract}

This research aimed at: (1) identifying the authentic materials written in "Cambridge Primary English Stage 4 Learner's Book”; (2) describing how authentic materials are implemented to teach reading; and (3) describing the problems in implementing authentic materials to teach reading and solutions proposed by the teacher. This research was designed as qualitative case study conducted 
in Islamic International Private Elementary School in Surakarta. The subject of the research was the English teacher who teaches reading at the fourth grade of international class program (ICP). The research data were collected through observation, interview, teaching learning documents, textbook analysis and were analyzed by using interactive model proposed by Miles, Hubarman, and Saldana (2014). Findings of the research were: (1) the authentic materials used in "Cambridge Primary English Stage 4 Learner's Book” were: a) posters, b) book covers, c) cards, d) book index, and e) blurb. (2) The implementation of the use of authentic materials in "Cambridge Primary English Stage 4 Learner's Book" were: a) posters were used to inform the students the elements of the narrative text or story, b) book covers were used to analyse and guess the content of book or story which is including title, character, setting, plot, and mood based on its covers, c) cards were used by the teacher descriptive text, d) book index was used to teach ordered information and e) blurb was used to teach how to identify the content of the story book. Most of the authentic materials were used in pre-reading activities. (3) Five problems in implementing authentic materials to teach reading were: a) lack of the students' understanding of English grammar, b) the ability of the students to understand the content of the authentic materials was less, c) comprehensive linguistic competences to write correct sentence was less related to grammar function, d) language focus related the text which the students was going to write, and e) students'lack of vocabulary mastery. Four Solutions proposed by the teacher were (a) giving new vocabulary and stimulation words, (b) studying the other example of authentic material related to the material discussed, (c) having discussion with students, and (d) improving students' understanding about the discussed materials. It is recommended to use textbook entitled "Cambridge English Primary Stage 4 Learner's Book" not only in the school where the researcher conducted the research, but also in other elementary schools emphasing on teaching reading skill by using authentic materials.

Keywords: Authentic Material, Cambridge English Textbook, Reading Skill.

\section{INTRODUCTION}

In teaching reading different variety of texts or materials are used. Nuttall (1996: 172) states the wide variety of different types of text means that it is easier to find something that will attract the learner's attention and may even encourage further reading or reading for pleasure. Another point of view about the materials used to teach English is stated by Nunan (1992: 227). He states teaching materials are often the most substantial and observable component of pedagogy.

In addition, Crawford cited in Richards and Renandya (2002:84-87) claims materials obviously reflect the writer's views of language \& learning and teachers (and students) will respond according to how well these match their own beliefs and expectations. In line with the function of the materials used in teaching and learning process, Cunningworth (1995: 7) summarizes the role of materials in language teaching as the resources (spoken and written), resources for activities for learner practice and communicative interaction, reference sources for learners on grammar, vocabulary and pronunciation, stimulation and ideas for classroom activities, syllabus, and supports for less experienced teachers who have not yet gained in confidence. So, we could believe that materials are considered beneficial for the teachers to teach students.

In building a good understanding students should recognize a real language or text used in the society. In dealing with the real-life language or text the students are given the authentic text or authentic materials. It means the use of authentic text cannot be separated from the use of language in the real life.

Wallace (1992: 45) defines authentic text as "...real-life texts, not written for pedagogic 
purposes". Jacobson, Degener, and PurcellGates (2003) see authentic materials as printed materials, which are used in classrooms in the same way they would be used in real life. Richards (2007: 252) argues that authentic materials are preferred over created materials because they contain authentic language and reflect real-world use of language compared with the contrived content of much created material. As mentioned in the previous paragraph, sometimes, authentic materials are also called as authentic texts. Nuttall (1996: 172) states "authentic texts can be motivating because they are the proof that the language is used for real life purposes by real people". Moreover, they have a positive effect on comprehension and learner satisfaction (Berado, 2006). At this condition, teachers take important roles on the use of authentic materials to teach reading skill to their students. So, one of the ways to make the success of learning language in the classroom is by providing them the English textbook containing real life text.

In the development of teaching media, teachers could find authentic materials from many sources. They could also find some authentic materials to teach reading in the textbook. One of the purposes is to make the teaching learning process becomes more intereseting. Then, it could help teachers and students in exlplaining and understanding the topic discussed. It also gives the chance for them to enlarge their views about English itself.

There are so many authentic materials written in English textbooks published to fulfill the teaching and learning process needs specifically in teaching reading in every level of education. In elementary school, students experience themselves to learn wider materials. Thus, it has to be given more attention in learning English. Considering the explanation above, this research found the textbook which provide some authentic materials to help the teachers to teach reading entitled "Cambridge Primary English Stage 4 Learner's Book". It is one of the series of textbooks for primary or elementary school students. This book is created to support the English learning process that stimulate students' critical thinking, core listening, speaking, reading, and writing.

This research investigated the use of authentic materials in "Cambridge Primary English Stage 4 Learner's Book" in teaching reading at the fourth grade in Private Islamic International Elementary School in Surakarta. This school has two programs for international class program (ICP) and billingual class program (BCP). The research was couducted in international class program (ICP). K13 or Curriculum 2013 is not only used by the the international class program (ICP) which is known as the curriculum in every level of education in Indonesia right now, but also Cambrige Assessment International Education curriculum is also integrated in the teaching and learning process to achieve students' target in learning some subjects such as English Cambridge, Mathematics Cambridge and Science Cambridge. The school adds the word "Cambridge" to distinguish subjects in national curriculum and Cambridge curriculum.

Finally, this research investigated the use of authentic materials in "Cambridge Primary English Stage 4 Learner's Book" to teach reading in international class program (ICP). In relation to the previous definitions, this reserach aimed to answer the following research questions:

1. What are the authentic materials in "Cambridge Primary English Stage 4 Learner's Book" implemented to teach reading?

2. How are the authentic materials implemented in teaching reading?

3. What are the problems in implementing authentic materials to teach reading and solutions proposed by the teacher?

\section{RESEARCH METHOD}

This research used case study method. Ary et al. (2010: 29) state case study is a type of ethnographic research study that focuses on a single unit, such as one individual, one group, one organization, or one program which aims to 
attain a detailed description and understanding of the case. Creswell (2007: 73) also has the similar idea by saying that case study is an indepth exploration of a bounded system such as activity, event, process, or individuals based on extensive data collection. The sample of the research was one teacher named Teacher Ds. She taught English subject for grade 4 .

Since the data of this kind of research appear in words rather than numbers, the data were collected through some variety of ways. They were observation, interview, and document analysis. Observation was conducted in teaching time, while interview and data analysis were conducted outside the class. Then, they were analyzed by using interactive model proposed by Miles, Hubarman, and Saldana in 2014. The components of data analysis: interactive model is displayed in figure 1.

Figure 1. Components of Data Analysis: Interactive Model

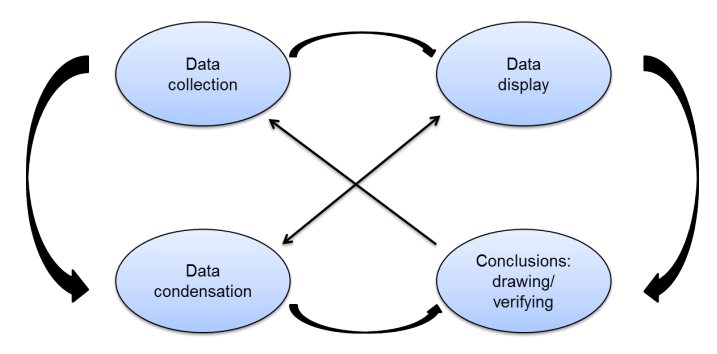

There are three concurrent flows of activity that should be done in this data analysis. They were data condensation, data display, and conclusion drawing and verification. But, gathering the data or data collection were done before data condensation. Furthermore, those three conncurrent flows of activity should be done in order. They were explain as follow:

\section{Data Condensation}

Data condensation refers to the process of selecting, focusing, simplifying, abstracting, and/ or transforming the data that appear in the full corpus (body) of written-up field notes or intervirew transcription, documents, other empirical materials. Further step of data reduction occured were writing summaries, coding, developing, generating categories, and writing analytic memos. By condensing, the researcher make the data stronger. The researcher did not use "data reduction" as a term because that implies they are weakening or losing something in the process. Data condensation was also considered as the part of the analysis.

\section{Data Display}

The second flow of analysis activity was data display. Miles, Huberman, and Saldana (2014: 11) define a data display as an organized, compressed assembly of information that permits conclusion drawing and action. Here, every data that has been selected in data condensation need to be presented correctly, so that, it could be easily interpreted by the researcher. Then, data display that has been popular in the qualitative research was displaying through extending words. Meanwhile, there some other ways to display the data such as by charts, graphs, and matrices.

\section{Conclusion Drawing and Verification}

The third stream of analysis activity was conclusion drawing or verification. The conclusion was seen as theory formulation. Miles, Huberman, and Saldana (2014: 11) mentioned that final conclusion may not appear until the data collection wis over; however, it also depends on the size of the fields, the coding, storage, and retreival methods used, but they often have been prefigured from the beginning, even the researcher sometimes claims to have proceedings inductively. Therefore, in drawing the conclusion, the researcher verified the data to the theory and previous researches.

\section{RESULT AND DISCUSSION}

Concerning to the results, it could be explained theoritically that the teacher used 5 kinds of authentic materials taken from the textbook that was used in class entitled "Cambridge Primary English Stage 4 Learner's Book" to teach reading during the first semester. They were posters book covers, cards, book 
index, and blurb. The data of this result were obtained from the observation in the class and textbook analysis. The other data were obtained from the interview in which one teacher was the participant and also the subject of the research.

\section{Five Authentic Materials Implemented to Teach Reading In the Class}

The first authentic material used to teach reading was poster. The purpose of using poster was to teach the elements of the story related to narrative text which includes plot, character of the story, setting, moral value, past tense, and the difference between fiction and non-fiction book. Gebhard (1996: 56) states four kinds of authentic materials; authentic listening viewing materials, authentic visual materials, authentic printed materials and realia (real word project used in EFL/ ESL classrooms to support the teaching reading processes. Here, poster belongs to authentic printed material since it is printed material that could be found in the textbook. Then, it also included to visual authentic materials because the students and teacher could see it by their visual aids or eyes. The other reason is because it is printed in the textbook that was used to teach reading. The teacher believed that poster belongs to authentic material because this material could be easily found in the daily life of the students. The previous explanation was in line with Nuttall (1996: 172) who claims authentic texts (that could be stated as authentic materials) can be motivating because they are proof that the language is used for real life purposes by real people. It is believed that poster was used to teach reading as the authentic material because it could be found easily in the real life by the students and teacher.

The second authentic material was book covers. Book covers are made not specially for languange teaching purposes, but it also could be used by the teacher to help the students in learning English. The example of book covers could find in some books in the school's library, book shops, museum or even in students' mini library at home. This is one of the reasons why book covers were included to authentic material as Jacobson et al (2003: 1) affirms authentic materials as printed materials which are used in classroom in the same way they would be used in real life.

The third authentic material in the textbook was cards. They provided some informations about sea animals in the form of pictures of the animals and each short description. This authentic material helped the students to see the pictures of the animals which were being described in the class, so that they did not only try to imagine it. Cards are included to the example of authentic-printed material as stated by Gebhard (1996: 56) when he gives more examples of authentic materials EFL/ ESL teachers have used.

After that, book index was included to the fourth authentic material in "Cambridge Primary English Stage 4 Learner's Book". The reason in based on Nunan (1999: 79) statement that defines authentic materials as spoken or written language data that have been produced in the course of genuine communication and not specifically written for purposes of language teaching. In fact, in his teaching he encourages his students to bring into the classroom their own samples of authentic language data from real-world contexts outside of the classroom. As mention in the finding, the students used book index in the textbook for being used to learn ordered information, so it is included as authentic material.

The fifth authentic material was blurb. Blurb usually includes an extract from the book. Blurbs sometimes include a review or quotation from someone who has read it. This is also authentic materials because when the students find the other books in the librabry or bookstore usually they will also find the blurb in the back cover. Nunan (1999: 79) defines authentic materials as spoken or written language data that have been produced in the course of genuine communication, and not specifically written for purposes of language teaching. Blurb is also included to his criteria of authentic material definition. Blurb in the textbook was used to help the students in analyzing the content of the story book. 
Furthermore, in implementing the use of authentic materials to teach reading at this point, the issue includes the teaching documents (lesson plan and material) and teaching learning process. Lesson plan was arranged based on Cambridge Assessment International Education curriculum in supporting the teacher to teach reading by using authentic materials and the material was taken from "Cambridge Primary English Stage 4 Learner's Book". The lesson plan contains object no need of teacher name, subject, week, grade, semester, and academic year. It also provides some information such as time or week, date, main chapter, unit and topic, resources, main learning objective outcome, main activity and assignment, tools, and method.

The lesson plan was already arranged in the begining of new academic year. It is for the fourth grade students. Five kinds of authentic materials were implemented in five main activities and assignments written in the lesson plan. The lesson plan does not mention the activities that will be done by the students completely like the one arranged based on $\mathrm{K} 13$ or common curriculum used in Indonesia because it was created based on Cambrige Assessment International Education curriculum.

There were 11 main activities-assignment implemented by the teacher to teach reading in five meetings. They then develop five kinds of authentic materials which are included poster, cards, book covers, book index, and blurb in these main activities-assignments in teaching reading. The teacher did not mention in detail the activities that were done in the class in using every single authentic material to teach reading. She just mentioned the main-activities and assignments in every meeting, but the other activities were done in the class to meet the students' needs in using the authentic materials.

\section{Implementing Five Authentic Materials}

Teaching reading in the class the teacher used five authentic materials taken from "Cambridge Primary English Stage 4 Learner's Book". They are posters, book covers, cards, book index, and blurb. Posters were used to teach the elements of narrative story. At the begining of teaching process the teacher prepared her own example of poster then she asked the students to guess what the elements of the story are just by using that poster. Then, she selected picture of fantasy story competition poster in the textbook that tells about the correct elements of the story. It means she elaborated two posters by providing the task in the form of reading and analyzing poster in pairs before reading the complete narrative text. Related to this result of the observation, Byrnes (2002: 4) mentions some examples of pre-reading activities are looking at pictures, maps, diagrams, or graphs and their caption and talking about the author's backgroud. Finally, the activity of using poster in this teaching and learning process was the example of pre-reading activity since the poster was used before reading the narrative text and analyzing its elements.

Then, book covers were used by the teacher to support her in teaching the students how to guess and analyse the content of book or story. She gave the example of book cover which was used to teach narrative text taken from Cambridge Primary English Stage 4 Learner's Book entitled "Where the Mountain Meets the Moon". She used this kind of authentic material to help the students to guess and identify the character, mood, and tune of the story before reading the complete text of the story. Since book cover was used to guess the content of the book or story before the students read the complete story, so this authentic material was used in pre-reading activity wich the students were stimulated to do reading text. It is in line with Byrnes (2002: 4) theory that mentions the example of pre-reading activities is the time where students are stimulated to do reading activity.

Besides, the teacher used cards to teach the students descriptive text. They are printed in the textbook used in the class. In the begining of teaching reading by using cards the teacher instructed the students to see the example of the real cards. There are some sea animals that 
were not familiar for the students. Then, she demonstrated every single card in English by using some short descriptions before giving the texts contain the information of each animal in the cards. She also asked the students some questions related to the animal printed in the cards. Then, the teacher instructed the students to open cards in the textbook. Based on this analysis the teacher used cards in the textbook before she explained descriptive text. It means cards were used in the pre-reading activity. It is in line with the example stated by that Byrnes (2002: 4) that mentions some examples of pre-reading activities are looking at pictures, maps, diagrams, or graphs and their caption and talking about the author's backgroud.

Furthermore, the purpose of implementing book index was the teacher used it to teach the students ordered information. At the begining of the class, the teacher instructed the students to analyse the content of book index individually. They should read the words in the book index and the numbers written beside the words or phrases there. Then, the students could understand that the book index contains the information of the words or phrases and the numbers of pages show where the information refers to the words or phrases. This activity informed us that book index was used in prereading activity because the students were asked to look at the book index in the textbook before they analyzed it and this activity was in line with Byrnes (2002: 4) theory that informs us some examples of pre-reading activities are looking at pictures, maps, diagrams, or graphs and their caption and talking about the author's backgroud. Beside, the data showed that book index was also used in while-reading activity. The teacher stated after looking at the book index the students were asked to read the specific content it. Then, they try to understand its information better. This activity was in line with the theory stated by Fauziati $(2010: 41)$ in while-reading the students should understand the specific informations. The teacher also asked the students the function of the words and numbers written in book index refers to the information in its book, it means she has instructed the students to have a depper analysis of the book index and this activity was in line with Barnett (1988) statement in which post-reading exercises first check students' comprehension and then lead students to a deeper analysis of the text.

It could be analysed based on the data of the research that the teacher also used blurb as the authentic material taken from Cambridge English Primary Stage 4 Learner's Book. It was used by the teacher to teach the students how to identify the content of story book. It means blurb was used in pre-reading activity. The result was in line with the theory stated by Byrnes (2002: 4) that mentions the example of pre-reading activities is the time where students are stimulated to do reading activity by looking at the picture, maps, diagrams, or graphs and their caption and talking about the author's backgroud.

\section{Five Problems and Solutions Proposed}

There were five problems stated by the teacher in implementing the authentic materials taken from Cambridge Primary English Stage 4 Learner's Book to teach reading in the class.

The first and second problem found in implementing posters to teach reading. The first problem was in the students' ability in understanding English grammar becuase usually posters use different types of tenses. Posters could also be written present tense, past tense, future tense, or perfect tense. The second problem was the students' linguistic competences to write correct sentence was less related to grammar function. They students found difficulty when the teacher instructed them to write a poster by using their own sentences. Two previous explanations could be classified into the problems in implementing authentic materials to teach reading because Berardo (2006: 65) states that in using authentic material in teaching English in the class sometimes too many structures are mixed so lower levels have decoding the texts and the vocabulary might not be relevant to the students' 
immidiate needs. The solutions proposed was by giving the other example of poster and explaining its short information. Besides, the teacher also used stimulation words related to the sentences of the poster.

The second problem was the students' understanding of the content of the authentic materials. The students found the diffculty when they were commanded to find the character and plot from the story based on short information in poster. The similar problem was same not shamed to happen on the implementation of book covers to teach reading. The students did not understand clearly the meaning of the picture and the information content. Furthermore the same problem was also happened in implementing book index in one sentence not separated to teach reading related to numbers and words. The students did not understand the function of the numbers in the book index and sometimes the students thought that book content book index were the same, in fact both are different. Then, the students were litle bit confused in reading book index. Besides, book index was not so familiar for the students in the class. Then, the teacher also stated that book index just provides the information in the form of words not sentence, so that the students did not understand the purpose of the written words in book index. The problem was in line with Berardo (2006: 65) who affirms one of disadvantages in using authentic materials is often too culturally biased, difficult to understand outside the language community. The teacher proposed the solution by showing the other example of poster, book covers, and book index then she tried to explain its short information. The teacher also gave the new words everyday taken from the textbook to the students.

The third problem was the students' language focus related the text which the students was going to write. The students' ability to write the correct sentence was less related to grammar function. They also had some difficulties in writing descriptive text correctly because they should demonstrate something.
This problem was in line with Richard (2001: 253) who proposes the authentic materials often contain difficult language, unneeded vocabulary items, and complex language structures, which can often create problems. Then, sometimes too many structures in authentic materials can create difficulty. The first solution proposed was the students were given stimulation words by playing canning game. In addition, the teacher gave the other examples of cards to help the students in understading decsriptive text. Then, the students were asked to learn the sentence written in present tense taken from the textbook while the teacher guided them to understand it.

The fifth problem was the lack of students' vocabulary mastery when the teacher implementing blurb to teach reading. The problem was in line with Berardo (2006: 65) who affirms the disadvantages of using authentic material in the teaching and learning process are vocabulary might not be relevant to the student's immediate needs and too many structures are mixed so lower levels have decoding the texts. In this case, the teacher proposed the solution by giving the students the other example of book that has its review or blurb at the back cover. Then, she asked the students to find out the blurb's criteria through its content. The next solution was by giving the new words everyday taken from the textbook to the students in the class to overcome the lack of students' vocabulary mastery.

\section{CONCLUSION AND SUGESTION}

Five authentic materials were used by the teacher to teach reading. They were posters, book covers, cards, bok index, and blurb. In implementing the use of authentic materials to teach reading the data including teaching documents (lesson plan and material) and teaching learning process showed that most of the authentic materials were used in pre-reading activities.

Five problems were found in implementing the authentic materials to teach reading such as the students' understanding of English grammar, the content of authentic material, 
comprehensive linguistic competences to write correct sentence was less related to grammar function, language focus related the text which the students was going to write, and students' lack of vocabulary mastery. Five solutions proposed by the teacher were giving new vocabulary and stimulation words, studying the other example of authentic material related to the material discussed, having discussion, and improving students' understanding about the materials being discussed.

Furthermore, the findings of this study suggest a more deeply investigation related to the issue of this study. This research was expected to give suggestions for institutions, teachers, and students as well as future researchers. For Educational Institutions is in achieving the objective of teaching foreign language the educational institution should lead the teachers to be more innovative and creative in using any kinds of authentic materials. Facilitating teachers to explore themselves concerning different variety of teaching materials is the educational institution should do. The educational institutions should also provide teacher training toward the use of teaching materials in order to enrich the teacher's knowledge of authentic materials. She can be more knowledgeable in improving the students' language skills. Attention has to be paid toward the use of authentic materials in the textbook in all language skills.

Next, for teachers they are suggested to always use authentic materials in supporting their teaching process as the materials that can stimulate and provide the students to experience the real language in the real life taken from the textbook and the other resources. Another reason was because some researchs found the result that the authentic materials provided in the textbook could atract the students to be more motivated. The teaching technique used by the teacher should also be effective and creative.

For students and future researchers, authentic materials are considered as the materials that can be easily accessied by students. Here, the students are suggested to use it to improve their ability to be more communicative as the indication of successfull learning of English. It is assumed that the students should also improve their English ability through the additional materials inside and outside the class beside authentic materials. Then, for future reseachers it is challenging to explore deeply toward this study. The other reseachers can conduct the next study related to the use of authentic materials in teaching other skills such as listening, speaking, and writing.

\section{REFERENCES}

Ary, D., Jacobs, L.C, \& Sorensen, C. K. (2010). Introduction to Research in Education: Eighth Edition. Wadsworth: Cengage Learning.

Barnett, M. A. (1988). Teaching Reading in a Foreign Language. USA: ERIC Clearinghouse on Language and Linguistics.

Berardo, S. A. (2006). The Use of Authentic Materials in the Teaching of Reading. The Reading Matrix Journal Vol. 6 No. 2 Page 60- 67.

Byrnes, H. (2002). The role of task and taskbased assessment in a content-oriented collegiate foreign language curriculum. Language Testing Journal Vol. 19 No.4 Page 419-437.

Creswell, J. W. (2007). Qualitative Inquiry and Research Design: Choosing Among Five Approaches. Thousand Oaks: Sage Publication

Cunningsworth, A. (1995). Choosing Your Coursebook. Oxford: Macmillan Heinemann.

Fauziati, E. (2010). Teaching English as Foreign Language (TEFL). Surakarta: Era Pustaka Utama.

Gebhard, J., G. (1996). Teaching English as a Foreign Language: A Teacher SelfDevelopment and Methodology. Ann Arbor: The University of Michigan Press. Jacobson, E., Degener, S., \& PurcellGates, V. (2003). Creating Authentic Materials and Activities for the Adult 
Literacy CClassroom: A Handbook for Practitioners. Boston: NCSALL at World Education.

Miles, M. B, Huberman, A. M, and Saldana, J. (2014). Qualitative Data Analysis. United States of America: SAGE Publications.

Nunan, D. (1992). Research Methods in Language Learning. Cambridge: Cambridge University Press.

Nuttal, C. (1996). Reading Skills in a Foreign Language. Oxford: Heineman.
Richard, J.C. (2001). Curriculum development in language teaching. Cambridge: Cambridge University Press.

Richards, J. C. and Renandya, W. A. (2002). Methodology in Language Teaching. Cambridge: University Press.

Richards, J. C. (2007). Curriculum Development in Language Teaching. Cambridge University: Cambridge University Press.

Wallace, C. (1992). Reading. Oxford: Oxford University Press. 